\title{
Freezing Temperature Effect on Survival of Puccinia graminis subsp. graminicola in Festuca arundinacea and Lolium perenne
}

\author{
W. F. Pfender and S. S. Vollmer, National Forage Seed Production Research Center, USDA-ARS, 3450 S.W. Cam- \\ pus Way, Corvallis, OR 97331
}

\begin{abstract}
Pfender, W. F., and Vollmer, S. S. 1999. Freezing temperature effect on survival of Puccinia graminis subsp. graminicola in Festuca arundinacea and Lolium perenne. Plant Dis. 83:10581062.

The Willamette Valley in Oregon is a major seed production area for cool-season grasses. Puccinia graminis subsp. graminicola survives over winter on its hosts as uredinial infections and causes epidemics of stem rust, the area's major disease on perennial ryegrass and tall fescue. To determine the possible importance of freezing temperature on rust survival, infected plants taken from the field were subjected to controlled freezing across a range of temperatures representative of those that can occur in the region. After treatment, plants were placed in a warm greenhouse, and the number of actively sporulating pustules was recorded at 3-day intervals for 21 days. The pathogen responded similarly to freezing treatments whether in perennial ryegrass or tall fescue. Compared with the nontreated standard, there was no significant reduction in pustule number after exposure to -3 or $-6^{\circ} \mathrm{C}$. Exposure of infected plants to $-10^{\circ} \mathrm{C}$ caused a 75 to $90 \%$ reduction in rust survival, and exposure to $-13^{\circ} \mathrm{C}$ killed all rust infections in tall fescue and over $99 \%$ in perennial ryegrass. The decline in rust survival with temperature was slightly steeper for perennial ryegrass than for tall fescue. A higher absolute number of infections in perennial ryegrass than in tall fescue resulted in higher numbers of surviving infections on perennial ryegrass. Survival of rust infections appeared to be primarily a function of host tissue survival. Between 1960 and 1997, years with winter temperatures as low as -10 or $-13^{\circ} \mathrm{C}$ have occurred in the Willamette Valley with frequencies of approximately 39 and $8 \%$, respectively. We conclude that year-to-year variation in winter temperature could have a significant effect on the survival of the grass stem rust pathogen.
\end{abstract}

Oregon's Willamette Valley is a major production area worldwide for seed of cool-season grasses, including tall fescue (Festuca arundinacea) and perennial ryegrass (Lolium perenne) (10). The most important disease on these two crops in Oregon, in terms of yield loss and management cost, is stem rust caused by Puccinia graminis subsp. graminicola. Yield reductions of $40 \%$ or more have been reported for unprotected crops (16). Sterolinhibiting fungicides may be applied as many as three and five times per season on tall fescue and perennial ryegrass, respectively, with an aggregate annual cost in the millions of dollars for Willamette Valley growers.

During the autumn, when green host tissue is available as newly planted seedlings or as regrowth from perennial crowns, pustules of $P$. graminis subsp. graminicola

Corresponding author: W. F. Pfender

E-mail: pfenderw@ucs.orst.edu

Accepted for publication 14 July 1999.

Publication no. D-1999-0827-01R

This article is in the public domain and not copyrightable. It may be freely reprinted with customary crediting of the source. The American Phytopathological Society, 1999. are common. The alternate host is rare or absent in the region, so local overwintering is on a grass host. Summer epidemics presumably are initiated by urediniospores produced locally in early spring from overwintering infections. Epidemic severity varies from year to year (15), and differences in the amount of overwintering inoculum may contribute to these variations.

For some other rust diseases of Poaceae, overwintering inoculum is known to have an influence on epidemic development. For wheat (Triticum aestivum) leaf rust (caused by $P$. recondita), epidemic severity was strongly correlated with winter and early spring weather, but not with late spring and summer conditions (2). In Kansas, maximum disease losses from wheat leaf rust were greater in years when the pathogen survived over winter locally than when it did not (9). Of the environmental factors affecting rust survival over winter, temperature is probably the most important. For example, the severity of wheat stripe rust (caused by $P$. striiformis) was positively correlated with temperatures of the preceding December and January $(3,4)$. Average January temperatures preceding severe stripe rust years were approximately $0^{\circ} \mathrm{C}$, whereas they were approximately $-7^{\circ} \mathrm{C}$ in years preceding mild stripe rust epidemics. Temperature also was found to be the most important factor explaining variation in overwinter survival of $P$. recondita (7).

There are no published data for lowtemperature survival of $P$. graminis subsp. graminicola, but the phenomenon has been studied for $P$. graminis subsp. graminis, a closely related pathogen of wheat. $P$. graminis subsp. graminis infections did not survive in wheat disease nurseries during four winters in Kansas, whereas $P$. recondita did survive all four winters (1). Also, the greatest number of consecutive days without airborne $P$. graminis subsp. graminis urediniospores occurred during the coldest winter months in Kansas (8). Although low-temperature survival of $P$. graminis subsp. graminis infections has not been studied under controlled conditions, survival of free urediniospores of this pathogen has been tested. When exposed outdoors to winter temperatures $<0^{\circ} \mathrm{C}, 97 \%$ of the urediniospores died after $72 \mathrm{~h}$, and none survived after $96 \mathrm{~h}$ (5). In a growth-chamber study, viability of $P$. graminis subsp. graminis urediniospores decreased to $<5 \%$ after $24 \mathrm{~h}$ at -4 to $-6^{\circ} \mathrm{C}$ (6). Although a few hours of exposure to below-freezing temperatures is very detrimental to unprotected urediniospores, others have suggested that spores survive better in uredinia than when they are exposed (2).

To the extent that early epidemic development of stem rust on grasses is conditioned by the amount of inoculum present in the spring, knowledge of the overwintering capabilities of the pathogen will be helpful in understanding epidemics. This research was done to assess survival of $P$. graminis subsp. graminicola in two grass hosts when subjected to the range of freezing temperatures that can occur in the Willamette Valley.

\section{MATERIALS AND METHODS}

Historical weather data. Air temperature records (1.5 $\mathrm{m}$ height), taken at Hyslop Experiment Farm near Corvallis for the Oregon Climate Survey, were examined to determine typical low temperature extremes that occur in the Willamette Valley grass seed production area. The lowest daily temperature that had occurred in each year during the period 1960 through 1997 was noted, and these data were used to construct a frequency distribution for annual low temperatures. In addition, hourly records for selected cold 
weather events were studied to determine typical cooling and warming rates $\left({ }^{\circ} \mathrm{C} / \mathrm{h}\right)$ for subfreezing weather in this locale.

Infected plant material. Perennial ryegrass (cv. Morningstar) and tall fescue (cv. Shenandoah) were sown in the field on 24 September 1997. On 16 October, plugs of the grasses $(7.5 \mathrm{~cm}$ diameter $)$ were transferred into pots, and the pots were set back into the ground for later retrieval. On 24 October, plants were inoculated by misting lightly with water, then dusting with a mixture of freshly collected urediniospores and talc $(0.3 \mathrm{mg}$ of spores in $0.1 \mathrm{~g}$ of talc per pot). Symptoms were visible by 10 November. Several light freezes ( -1 to $-2^{\circ} \mathrm{C}$ ) occurred in the field during December and early January. On 15 January 1998, pots were removed from the field, randomized, and exposed to freezing temperature treatments. Pots of each grass species were buried to the rim in a tub of wet soil, and the tub was placed on a Styrofoam board in a freezer (Forma Scientific, Marietta, $\mathrm{OH}$ ) equipped with a programmable controller (West Instruments, East Greenwich, RI). Plants were precooled at 0 or $-1^{\circ} \mathrm{C}$ for several hours before imposing the freeze treatments. The freezer was set to reach low temperatures of $-3,-6,-10$, or $-13^{\circ} \mathrm{C}$ in the various treatments, with rates of cooling and warming $\left({ }^{\circ} \mathrm{C} / \mathrm{h}\right)$ as shown in Table 1 . When pots were removed from the freezer, they were placed for several hours in a growth chamber set at $0.5^{\circ} \mathrm{C}$, then were moved to a greenhouse kept at 18 to $22^{\circ} \mathrm{C}$ for 3 weeks.

Data collection and experimental design. Before plants were exposed to the freeze treatments, the number of pustules per pot was recorded. After the plants were removed from the freeze treatment, they were examined at 3-day intervals for 21 days. At each sampling time, the number of actively sporulating pustules per pot was recorded. These uredinia represent infections that survived the freeze treatment, either as pustules or as latent infections that erupted after the plants were moved to warm conditions. Viability of urediniospores in three to five pustules per pot was assessed at 9 and 17 days after freezing. Spores from each pustule were transferred to water agar and incubated overnight in the dark; then 50 spores per pustule were examined microscopically to determine percent germination. Spores were considered germinated (viable) if the germ tube length exceeded the spore diameter.

For each freeze treatment, five randomly selected pots (replicates) were used per grass species. Each pot was considered a replicate in a statistical analysis of active pustules. For analysis of spore viability in these active pustules, germination data for several pustules per pot were averaged to provide each replicate value. To analyze spore viability data from the relatively small number of inactive pustules, each pustule was treated as a single observation. The entire experiment was repeated in early February using newly collected pots of plants from the field. Data analyses were performed with SAS software (SAS System for Windows, Release 6.11, SAS Institute, Cary NC) using ANOVA, REG, or GLM procedures as appropriate.

\section{RESULTS}

Willamette Valley weather records. During the period 1960 to 1997 , a temperature at least as low as $-3^{\circ} \mathrm{C}$ was reached in all years (Table 2). In 27 (71\%) of the 38 years, the coldest temperature reached was $-6^{\circ} \mathrm{C} ;-10^{\circ} \mathrm{C}$ was the coldest temperature in 15 of the years (39\%); and $-13^{\circ} \mathrm{C}$ was the coldest temperature reached in 4 of the years $(8 \%)$. Typical cooling rates ranged from -0.4 to $-1.5^{\circ} \mathrm{C} / \mathrm{h}$, and warming rates were 0.3 to $1.3^{\circ} \mathrm{C} / \mathrm{h}$. The number of hours below freezing varied greatly for different cold events, and freezing duration typically was longer for events in which a lower temperature was reached. The freezing durations chosen for experimental treatments (Table 1) are similar to those of selected actual events.

From these historical weather data, experimental treatments of $-3,-6,-10$, and $-13^{\circ} \mathrm{C}$ were chosen to represent cold extremes that occur with approximately the following frequencies: every year, 7 of 10 years, 4 of 10 years, and 1 of 10 years, respectively. A standard treatment, in which plants from the field were placed directly in the warm greenhouse without further freeze treatment, was included. The standard treatment is labeled " $0{ }^{\circ} \mathrm{C}$ " in the graphical presentations of data.

Initial pustule density. Pretreatment observations of pots brought in from the field showed that perennial ryegrass had significantly $(P<0.01)$ more infections
(27 per pot) than tall fescue ( 5 per pot) The number of pustules averaged across the five pots chosen randomly for each freeze treatment ranged from 3.4 to 6.6 (standard deviation $=4.5$ ) in tall fescue, and from 20.2 to 43.8 (standard deviation = 17.2) in perennial ryegrass. Although these pustules appeared to be alive (not necrotic), none was actively producing urediniospores at the time the plants were collected from the field.

Survival of rust infections exposed to freeze treatment. The two experiments gave similar results with regard to the relative effects of temperature on survival of pustules and latent infections, and the results of one experiment are given in Figure 1A and B. In tall fescue (Fig. 1A), pustule production on plants exposed to -3 and $-6^{\circ} \mathrm{C}$ was similar to that on plants exposed to no additional freezing (standard). Some sporulating pustules were present as early as 3 days after freezing. We observed (data not shown) that the latent period, i.e., time duration between initial infection and eruption of a pustule from the infection, was 10 to 14 days for tall fescue and 8 to 12 days for perennial ryegrass under our greenhouse conditions. Therefore, these early pustules must have arisen from infections that were latent at the time of freeze treatment. The maximum number of sporulating pustules was reached by 8 to 11 days; then the number of active pustules decreased as

Table 2. Frequency of annual low air temperature extremes in the Willamette Valley of Oregon, 1960 to $1997^{\mathrm{a}}$

\begin{tabular}{|c|c|c|}
\hline \multirow{2}{*}{$\begin{array}{l}\text { Lowest daily } \\
\text { temp. }\left({ }^{\circ} \mathrm{C}\right)\end{array}$} & \multicolumn{2}{|c|}{$\begin{array}{c}\text { Frequency of occurrence } \\
\text { (years) }\end{array}$} \\
\hline & Number & $\%$ \\
\hline-2 & 38 & 100 \\
\hline-3 & 37 & 97 \\
\hline-4 & 36 & 95 \\
\hline-5 & 34 & 89 \\
\hline-6 & 27 & 71 \\
\hline-7 & 22 & 58 \\
\hline-8 & 20 & 53 \\
\hline-9 & 17 & 45 \\
\hline-10 & 15 & 39 \\
\hline-11 & 12 & 32 \\
\hline-12 & 7 & 18 \\
\hline-13 & 3 & 8 \\
\hline-14 & 1 & 3 \\
\hline
\end{tabular}

${ }^{a}$ Data collected at the Hyslop Experimental Farm weather station.

Table 1. Freezing treatments applied to rust-infected grass

\begin{tabular}{|c|c|c|c|c|c|c|}
\hline \multirow[b]{2}{*}{$\begin{array}{l}\text { Low temperature } \\
\left({ }^{\circ} \mathrm{C}\right)\end{array}$} & \multicolumn{6}{|c|}{ Time and temperature conditions for treatment components } \\
\hline & Precool & $\begin{array}{l}\text { Freeze rate } \\
\quad\left({ }^{\circ} \mathbf{C} / \mathbf{h}\right)\end{array}$ & $\begin{array}{l}\text { Dwell time at low } \\
\text { temperature (h) }\end{array}$ & $\begin{array}{c}\text { Warm rate } \\
\left({ }^{\circ} \mathbf{C} / \mathbf{h}\right)\end{array}$ & $\begin{array}{l}\text { Total time below } \\
0^{\circ} \mathrm{C}(\mathrm{h})\end{array}$ & $\begin{array}{c}\text { Postfreeze time at } \\
0.5^{\circ} \mathrm{C}(\mathrm{h})\end{array}$ \\
\hline Standard $^{\mathrm{a}}$ & & & $\cdots$ & & 0 & \\
\hline-3 & $0 \mathrm{~h}$ at $0^{\circ} \mathrm{C}$ & 0.5 & 2 & 0.5 & 14 & 0.5 \\
\hline-6 & $3 \mathrm{~h}$ at $0^{\circ} \mathrm{C}$ & 1.0 & 7 & 1.0 & 19 & 2 \\
\hline-10 & $3 \mathrm{~h}$ at $-1^{\circ} \mathrm{C}$ & 1.5 & 11 & 1.5 & 27 & 3 \\
\hline-13 & $9 \mathrm{~h}$ at $-1^{\circ} \mathrm{C}$ & 1.5 & 12 & 1.5 & 37 & 3 \\
\hline
\end{tabular}

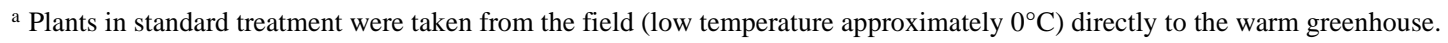


some leaves senesced. Few active pustules were produced on tall fescue plants exposed to $-10^{\circ} \mathrm{C}$, and no active pustules were produced on tall fescue exposed to $-13^{\circ} \mathrm{C}$. In perennial ryegrass, the effect of freezing on stem rust survival and activity was similar to that in tall fescue, but higher numbers of pustules developed (Fig. 1B). Active pustules were present on plants exposed to $-3^{\circ} \mathrm{C}$ and the standard treatment by 3 days after freezing. By 11 days after freezing, the standard, -3 , and $-6^{\circ} \mathrm{C}$ treatments had reached their maximum production of active pustules. After exposure to $-10^{\circ} \mathrm{C}$, active pustules on perennial ryegrass were fewer than in the $-6^{\circ} \mathrm{C}$ treatment, but more than on tall fescue exposed to $-10^{\circ} \mathrm{C}$. On perennial ryegrass exposed to $-13^{\circ} \mathrm{C}$, only one active pustule was found on all plants in both experiments.

To analyze the effect of temperature on survival of rust infections, the maximum number of active pustules per pot was examined using ANOVA and regression analysis. ANOVA showed no significant effect of experiment, so data from both experiments were combined for regression analysis of each grass species. The number of pustules produced was not linear with temperature, but a logarithmic transformation gave an approximately linear relationship (Fig. 1C and D). Inspection of the data showed that variance in pustule number differed with temperature treatment, with the variance being approximately proportional to the square of treatment means. Therefore, a weighted least squares regression analysis was performed using $[\ln (\text { average pustules }+1)]^{-2}$ as weights. For tall fescue (Fig. 1C), there was no effect of temperature from 0 to $-6^{\circ} \mathrm{C}$ on pustule production. Maximum pustule numbers per pot were $5.9,8.3$, and 5.3 for $0,-3$, and $-6^{\circ} \mathrm{C}$ treatments, respectively. From -6 to $-13^{\circ} \mathrm{C}$, the number of active pustules per pot decreased with temperature (Fig. 1C). For perennial ryegrass (Fig. 1D), there was likewise no significant effect of temperature on infection survival from 0 to $-6^{\circ} \mathrm{C}$, with maximum pustule numbers of 53,49 , and 51 for $0,-3$, and $-6^{\circ} \mathrm{C}$, respectively. Pustule number decreased with temperature from -6 to $-13^{\circ} \mathrm{C}$.

Urediniospore viability. Spores taken from actively sporulating pustules showed no consistent effect of prior temperature treatment on viability, and percent germination was generally high ( $>55 \%$ ) (data not shown). However, urediniospores from tall fescue consistently had lower percent viability than those collected from perennial ryegrass. Among spores sampled 9 days after the freeze treatments, percent germination (averaged over all temperatures) of spores from perennial ryegrass was $79 \%$, which was significantly $(P=0.001)$ greater than the $63 \%$ average germination of spores from tall fescue. When sampled 17 days after freeze treatments, average viabilities of urediniospores from perennial ryegrass and tall fescue were 88 and $75 \%$, respectively (difference between hosts significant at $P=0.001$ ).

Because few or no actively sporulating pustules were produced on plants that had been exposed to -10 and $-13^{\circ} \mathrm{C}$, urediniospores were sampled from inactive pustules on these plants to assess their possible importance as viable inoculum. These uredinia, erumpent but relatively flat in appearance, had been present before the freeze treatments, and thus their spores had been exposed to -10 or $-13^{\circ} \mathrm{C}$. In contrast to spores from active pustules, spores from inactive pustules had a lesser and more variable percent viability. For these spores, there was no detectable difference in viability attributable to grass species. When averaged across the two species, inactive pustules that had been exposed to -10 and $-13^{\circ} \mathrm{C}$ yielded spores that were 11 and $4 \%$ viable, respectively (difference not significant at $P=0.05$ ). The overall mean viability of spores from inactive pustules was significantly $(P=0.001)$ less than the $72 \%$ average viability of spores from active pustules on both grass species that had been exposed to $-10^{\circ} \mathrm{C}$.

Freeze damage to plants and plant tissue. Tall fescue and perennial ryegrass were similar in sustaining little damage
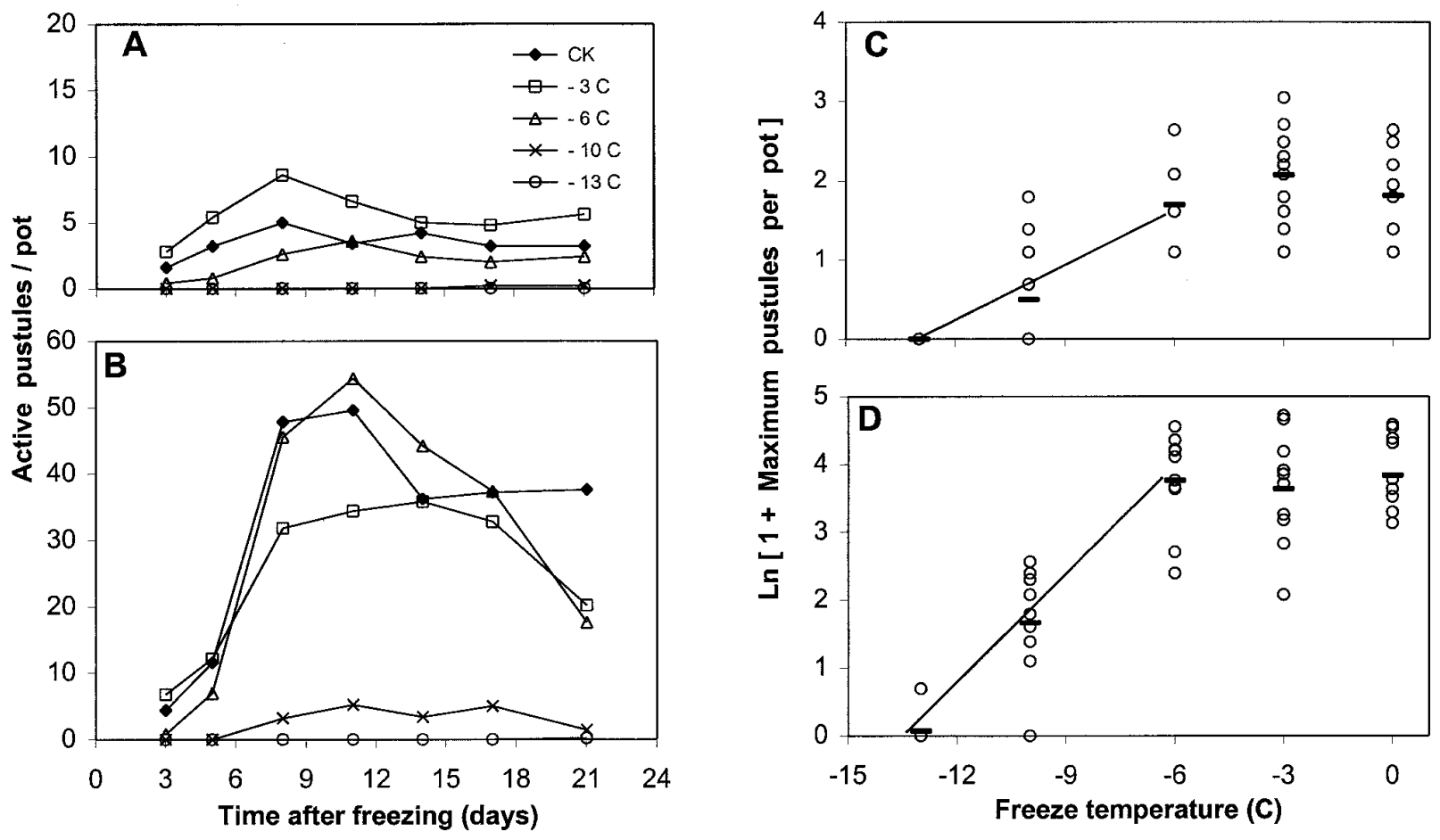

Fig. 1. Effect of freezing temperature on subsequent pustule development in tall fescue $(\mathbf{A}, \mathbf{C})$ and perennial ryegrass $(\mathbf{B}, \mathbf{D})$. Time course for appearance of actively sporulating pustules at 3-day intervals following completion of freezing treatment for (A) tall fescue and (B) perennial ryegrass. Maximum number of rust pustules (logarithmic transformation) present per pot during the 21 days following freezing for tall fescue (C) and perennial ryegrass (D). Circles indicate experimental observations, and dark dashes show treatment averages. Linear regression lines for transformed pustule numbers over temperatures from -6 to $-13^{\circ} \mathrm{C}$ are shown. Regression equation for tall fescue $(\mathbf{C}): Y=2.875+0.0314 X$ for $X=-6$ to -13 , adjusted $R^{2}=0.63,28$ df. Regression equation for perennial ryegrass (D): $Y=6.941+0.0400 X$ for $X=-6$ to -13 , adjusted $R^{2}=0.86,28 \mathrm{df}$. 
from exposure to -3 or $-6^{\circ} \mathrm{C}$ ( 2 to $4 \%$ of the leaves were killed), and no plants died. At -10 and $-13^{\circ} \mathrm{C}$, tall fescue was more severely damaged than perennial ryegrass. At $-10^{\circ} \mathrm{C}$, most of the individual tall fescue leaves were killed and $92 \%$ of its tillers died, and at $-13^{\circ} \mathrm{C}$ all of the tall fescue plants were killed. At $-10^{\circ} \mathrm{C}$, only $50 \%$ of the perennial ryegrass leaves were killed. At $-13^{\circ} \mathrm{C}, 0.5 \%$ of the original perennial ryegrass leaves survived as possible rust host material, and $4 \%$ of its tillers survived to produce new leaves.

\section{DISCUSSION}

Our tests were designed to simulate naturally occurring cold temperature events. Steffen et al. (13) noted that experiments with unnaturally extreme freezing rates, and/or supercooling due to lowtemperature ice nucleation, gave results that have limited relevance to natural phenomena. Therefore, we used cooling rates $<2{ }^{\circ} \mathrm{C} / \mathrm{h}$ (Table 1) and exposed plants to a precooling period to assure that cold temperatures were achieved throughout the plant tissue as it cooled. Also, because plants were taken from the field, we assumed ice nuclei to be present on them. However, in keeping with our goal of simulating natural cold-temperature events, no attempt was made to separate effects of temperature from those due to duration of freezing. For example, plants exposed to $-13^{\circ} \mathrm{C}$ were below freezing for a longer duration than plants exposed to $-6^{\circ} \mathrm{C}$.

Freezing temperatures lower than $-6^{\circ} \mathrm{C}$ affected the survival of rust infections in both grass species. Rust survival was closely associated with survival of plant tissue. Neither rust nor plant leaves were affected at $-6^{\circ} \mathrm{C}$, and both were greatly harmed at $-10^{\circ} \mathrm{C}$ and nearly completely destroyed at $-13^{\circ} \mathrm{C}$. In perennial ryegrass, rust infections may be damaged in a slightly greater proportion than visible plant damage. For example, in this study, at $-10^{\circ} \mathrm{C}$ rust infection in perennial ryegrass was reduced by $90 \%$ and plant tissue by only $50 \%$. For tall fescue, this discrepancy between rust reduction $(75 \%)$ and plant damage $(85 \%)$ at $-10^{\circ} \mathrm{C}$ was not observed.

The $-13^{\circ} \mathrm{C}$ treatment caused a greater frequency of plant death (100 and 96\% for tall fescue and perennial ryegrass, respectively) than would likely occur at $-13^{\circ} \mathrm{C}$ air temperature in the field. Previous research (12) indicated that perennial ryegrass roots were more susceptible to freeze damage than shoots, with crowns intermediate in freeze resistance. In our experiments, roots and crowns probably reached the low temperatures imposed, whereas under field conditions the larger soil mass would likely provide a greater degree of temperature buffering. For example, historical weather data for the Willamette Valley showed that roots at the 5-cm depth experienced temperatures as low as $-3^{\circ} \mathrm{C}$ in only $19 \%$ of the past 37 years, and $-6^{\circ} \mathrm{C}$ in none of these years (data not shown; compare with air temperatures, Table 2). The crowns are generally at or slightly below the soil surface, which would likely prevent the crown temperature from falling as low as the air temperature. The result is that plant survival would probably be higher after the $-13^{\circ} \mathrm{C}$ air temperature in the field than after the $-13^{\circ} \mathrm{C}$ treatment in our experiments. Even in the field, however, the rust-infected leaves would be killed by $-13^{\circ} \mathrm{C}$, and the leaves that eventually regrew would not initially carry rust infections. Therefore, our observations of rust survival with respect to temperature are probably indicative of rust response in the field. Most of the rust pustules that we observed after the $-10^{\circ} \mathrm{C}$ treatment, and the single active pustule observed in perennial ryegrass after the $-13^{\circ} \mathrm{C}$ treatment, were located near the leaf bases where some leaf tissue had survived freezing.

Previous studies using greenhousegrown plants showed universally fatal damage to shoots at and below freezing temperatures of $-8^{\circ} \mathrm{C}$ for perennial ryegrass (13) and $-10.5^{\circ} \mathrm{C}$ for tall fescue (14). These values are similar to, but slightly warmer than, our observations. The cold-hardiness of our field-grown plants may be more representative of agricultural situations than of greenhouse-grown plants.

Although the rust response to freezing was broadly similar between the two grass species, there were some minor but consistent differences. Pustule formation on perennial ryegrass showed a greater decline with temperature between -6 and $-10^{\circ} \mathrm{C}$ than was observed on tall fescue (Fig. 1C and D). However, perennial ryegrass initially had more pustules per plant (typical of the difference between these grass species in the field), so it carried a larger absolute number of rust pustules than tall fescue did after exposure to $-10^{\circ} \mathrm{C}$. Perennial ryegrass plants were damaged less than tall fescue by -10 and $-13^{\circ} \mathrm{C}$, and spores from perennial ryegrass had a higher germinability than those from tall fescue.

In our experiments, $P$. graminis subsp. graminicola apparently survived freezing in grass tissue primarily as latent infections, that is, as established infections that had not yet proceeded to pustule eruption. In our experiments, some pustules erupted as early as 3 days after plants were moved to the warmer temperature, and most had erupted by 8 days. Given a latent period of 8 to 11 days under our greenhouse conditions, most pustules that appeared following the freeze treatments must have been at an early point in their development when plants were taken from the field. Hassan et al. (11), working with $P$. recondita in wheat, observed that infections more than $24 \mathrm{~h}$ old can survive most freezing condi- tions that the host tissue can survive. In our study, almost all pustules already erumpent when plants were removed from the field were "inactive" (i.e., no longer producing urediniospores) prior to and following the freeze treatment. Spores from these few inactive pustules had a relatively low percent germinability and therefore would have less importance than latent infections in early stages of epidemics.

These experiments demonstrate that freezing temperatures warmer than $-6^{\circ} \mathrm{C}$ had little effect on survival of rust infections in perennial ryegrass or tall fescue. Temperatures below $-6^{\circ} \mathrm{C}$ that persist longer than 24 to $36 \mathrm{~h}$ significantly reduced survival of latent infections and subsequent pustule formation on infected leaves. We conclude that low winter temperature may be a useful predictor of stem rust inoculum survival in the Willamette Valley.

\section{LITERATURE CITED}

1. Burleigh, J. R., Schulze, A. A., and Eversmeyer, M. G. 1969. Some aspects of the summer and winter ecology of wheat rust fungi. Plant Dis. Rep. 53:648-651.

2. Chester, K. S. 1943. The decisive influence of late winter weather on wheat leaf rust epiphytotics. Plant Dis. Rep. Suppl. 143:133144.

3. Coakley, S. M., and Line, R. F. 1981. Quantitative relationships between climatic variables and stripe rust epidemics on winter wheat. Phytopathology 71:461-467.

4. Coakley, S. M., Line, R. F., and McDaniel, L. R. 1988. Predicting stripe rust severity on winter wheat using an improved method for analyzing meteorological and rust data. Phytopathology 78:543-550.

5. Eversmeyer, M. G., and Kramer, C. L. 1994 Survival of Puccinia recondita and $P$ graminis urediniospores as affected by exposure to weather conditions at one meter. Phytopathology 84:332-335.

6. Eversmeyer, M. G., and Kramer, C. L. 1995 Survival of Puccinia recondita and $P$. graminis urediniospores exposed to temperatures from subfreezing to $35 \mathrm{C}$. Phytopathology 85:161-164.

7. Eversmeyer, M. G., and Kramer, C. L. 1996. Modeling winter and early spring survival of Puccinia recondita in wheat nurseries during 1980 to 1993. Plant Dis. 80:490-493.

8. Eversmeyer, M. G., Kramer, C. L., and Browder, L. E. 1984. Presence, viability, and movement of Puccinia recondita and $P$. graminis inoculum in the Great Plains. Plant Dis. 68:392-395.

9. Eversmeyer, M. G., Kramer, C. L., and Browder, L. E. 1988. Winter and early spring survival of Puccinia recondita on Kansas wheat during 1980-1986. Plant Dis. 72:1074-1076.

10. Fairey, D. T., and Hampton, J. G. 1997. Temperate forage seeds: An introduction. Pages 17 in: Forage Seed Production. Vol. 1, Temperate Species. D. T. Fairey and J. G. Hampton, eds. CAB International, New York.

11. Hassan, Z. M., Kramer, C. L., and Eversmeyer, M. G. 1986. Summer and winter survival of Puccinia recondita and infection by soilborne urediniospores. Trans. Br. Mycol. Soc. 86:365-372.

12. Laidlaw, A. S., and Berrie, A. M. M. 1977. The relative hardening of roots and shoots and the influence of day-length during hard- 
ening in perennial ryegrass. Ann. Appl. Biol. 87:443-450.

13. Steffen, K. L., Arora, R., and Palta, J. P. 1989. Relative sensitivity of photosynthesis and respiration to freeze-thaw stress in herbaceous species: Importance of realistic freeze-thaw protocols. Plant Physiol.
89:1372-1379

14. Thomas, W. D., and Lazenby, A. 1968. Growth cabinet studies into cold tolerance of Festuca arundinacea populations. III. Cold tolerance of roots and shoots. J. Agric. Sci. 70:355-360.

15. Welty, R. E., and Azevedo, M. D. 1994. Ap- plication of propiconazole in management of stem rust in perennial ryegrass grown for seed. Plant Dis. 78:236-240.

16. Welty, R. E., and Barker, R. E. 1992. Evaluation of resistance to stem rust in perennial ryegrass grown in controlled and field conditions. Plant Dis. 76:637-641. 